\title{
Peter Mendelsund and David J. Alworth: The Look of the Book. Jackets, Covers, and Art at the Edges of Literature
}

\section{Ten Speed Press/Crown/Penguin Random House, New York, NY, October 2020, 290 pp, Illustrated, \$50.00, Hardcover, ISBN: 9780399581021}

\section{Corinna Norrick-Rühl ${ }^{1}$ (i)}

Published online: 3 May 2021

(C) The Author(s) 2021

A recent talk by David J. Alworth at the Freie Universität Berlin brought my attention to his new publication, The Look of the Book, published in October 2020 with Ten Speed Press, a lesser-known imprint (under the umbrella of the Crown Publishing Group) of Penguin Random House. Alworth, whose work focuses on intersections of technology, culture, and society, co-created this fascinating book with Peter Mendelsund, who is currently the creative director of The Atlantic. Readers who are familiar with Mendelsund's What We See When We Read [1] will expect an approach that is both playful and thought-provoking, and this book does not disappoint.

Alworth and Mendelsund have merged their interests and expertise as a scholar (Alworth) and a designer and writer (Mendelsund) to produce a sumptuous (and heavy!) volume that will be of interest to scholars of book and publishing studies and of publishing and book history. It is, however, also accessible and inviting to a broader readership in and well beyond academia. Tellingly, the New York Times selected this book as one of the best coffee-table books of the year 2020 [2].

The book is divided into eight chapters, preceded by an ample preface (titled "Meeting at the Edge") which confirms Donald F. McKenzie's statement that books are 'friskier' and 'more elusive' than the words 'physical object' will allow [3, p. 334]. The preface includes a booklet of smaller-size pages bound into the book (pp. 15-50), delighting the reader and provoking questions about book design and book formats. The preface also reminds readers of books' dual status as commodity and cultural object, likening the function of book covers to that of bags of potato chips and television commercials (p. 55).

Corinna Norrick-Rühl

cnorrick@uni-muenster.de

1 University of Muenster, Muenster, Germany 
Chapter 1 ("What the Book Cover Is") covers (pun intended) details of book design and production and introduces terminologies (especially the detailed double-page spreads on pp. 62-63 and pp. 74-75), but also discusses book covers and their role in a wider media ecology. While chapter 1 briefly touches upon historical developments, chapter 2 ("What the Book Cover Was") gives a fuller historical account. The four-page timeline showing the chronological development of book covers through the decades (pp. 90-93), starting in the 1820s, will be immensely useful to anyone teaching book history or book design.

Chapter 3 ("What the Book Cover Does") considers the uses and functions that a book cover fulfills. Simply put, "Texts need paratexts as much as we do" (p. 165). Kazuo Ishiguro's The Buried Giant serves as an interesting example of the interconnections between the literary text and its outward-facing appearance. The connections between design, genre and audience are also discussed, and Alworth and Mendelsund emphasize the role of the cover designer in visualizing genre, from science fiction to romance to crime. An impressive double-page spread compares typical characteristics of mass-market thrillers (e.g. by John Grisham and Tom Clancy) with cover design for literary fiction titles (e.g. by Lesley Nneka Arimah or Zinzi Clemmons) (pp. 172-173); another instructive example is an overview of H. P. Lovecraft's works across time, driving the point home that "cover design tropes for various genres are not static" (p. 183).

The next chapter ("Why the Book Cover Matters") delves into the political and ethical implications of book design. The contradictory and problematic status of book covers in the industry, and their reinforcement of racist and sexist stereotypes comes to the fore. This calls Anamik Saha's groundbreaking work on the "rationalizing/racializing logic" of the book industry to mind, in which he discusses (among other forms of pigeonholing) cover design for books set in India (e.g. [4]).

Chapter 5 ("How the Book Cover is Made") considers the role of book covers as "data visualizations" (p. 220) with certain obligatory structures and defined spaces such as the spine of the book. As Alworth and Mendelsund say, "designing a book cover is a process of remediation and distillation" (p. 228). This chapter is followed by "Two Case Studies: Ulysses and Moby Dick" (chapter 6), which contain no text, only images. Ulysses in particular is referenced throughout Alworth and Mendelsund's book, and thus this chapter functions as a post-script to the earlier deliberations.

The book concludes with observations on "The Future of the Book Cover" (chapter 7) and "Conversations at the Edge" (chapter 8). In closing, Alworth and Mendelsund remind readers of the complexities of book design, and of the intimate connection between the people involved in book production and the final result.

A downside of the fantastic and elaborate design is that this book is difficult to read from cover to cover if you are trying to focus on the textual elements. A small font was chosen, and the layout varies between a handier two-column and wider one-column format. The heft of the book design and the countless illustrations, however, promote an immersive and intense reading experience. This book needs to be opened again and again to discover all the details and really profit from its elaborate design. Which brings me to a further drawback of this book: it will not work well in 
the zoom classroom. This instructive book can only fulfill its pedagogical potential in the post-pandemic era.

Funding Open Access funding enabled and organized by Projekt DEAL.

Open Access This article is licensed under a Creative Commons Attribution 4.0 International License, which permits use, sharing, adaptation, distribution and reproduction in any medium or format, as long as you give appropriate credit to the original author(s) and the source, provide a link to the Creative Commons licence, and indicate if changes were made. The images or other third party material in this article are included in the article's Creative Commons licence, unless indicated otherwise in a credit line to the material. If material is not included in the article's Creative Commons licence and your intended use is not permitted by statutory regulation or exceeds the permitted use, you will need to obtain permission directly from the copyright holder. To view a copy of this licence, visit http://creativecommons.org/licen ses/by/4.0/.

\section{Reference}

1. Mendelsund P. What we see when we read. A phenomenology. New York: Vintage; 2014.

2. Christensen L. Coffee-table books to give (and get) this season. The New York Times, December 3; 2020. https://www.nytimes.com/2020/12/03/books/review/seasons-best-coffee-table-books.html.

3. McKenzie DF. The sociology of a text: orality, literacy and print in early New Zealand. Library. 1984;s6-VI.4(December):333-65. https://doi.org/10.1093/library/s6-VI.4.333.

4. Saha A. The rationalizing/racializing logic of capital in cultural production. Med Ind. 2016;3:1. https://doi.org/10.3998/mij.15031809.0003.101.

Publisher's Note Springer Nature remains neutral with regard to jurisdictional claims in published maps and institutional affiliations. 